\title{
1. Introduction to comparative corporate governance
}

\author{
Afra Afsharipour and Martin Gelter
}

\section{COMPARATIVE CORPORATE GOVERNANCE-A SKETCH}

Comparative corporate governance has become a broad research field during the past decades. With the increasing internationalization of law and legal scholarship, the subject has seen a burgeoning volume of research from a practical, theoretical, and empirical perspective. There is no single predominant definition of corporate governance. Notably, the Cadbury Committee defined corporate governance as "the system by which companies are directed and controlled." Much more narrowly, Shleifer and Vishny have stated that "[c]orporate governance deals with the ways in which suppliers of finance to corporations assure themselves of getting a return on their investment." ${ }^{2}$ On the broad end of the definitional spectrum, Jonathan Macey suggested that corporate governance includes "[a]nything and everything that influences the way that a corporation is actually run." 3

Practically speaking, both internationally and within individual countries, most corporate governance research deals with the interaction between board members, officers, and shareholders, primarily in large, publicly traded corporations. Considerable volumes of literature thus are preoccupied with reducing conflicts of interest between shareholders and management, and consequently minimizing agency cost, thus vindicating the narrow finance perspective. Given the predominance of controlling shareholders around the globe, the literature increasingly focuses acutely on conflicts between controlling and minority shareholders. In a comparative or international context, research also often takes a broader perspective in that it includes all groups whose interests are affected by corporate activities and who have some degree of influence on corporations, such as creditors and employees.

This book attempts to take a broad perspective, even if most of the chapters deal with boards and shareholders and how they interact, both between and among each other (e.g. minority versus controlling shareholders), covering both legal duties and their enforcement, as well as the balance of powers generated by the institutional setup. Nevertheless, the interests of other "stakeholders" are very much present throughout the chapters. The authors also explore corporate purpose from various perspectives, namely short-termism, corporate social responsibility (CSR) and environmental, social, and governance (ESG) issues. Labor representation is discussed in the context of the board. Several of the chapters deal with corporate governance in times of transition, namely mergers and acquisitions. In terms of subject, the authors address

\footnotetext{
1 Adrian Cadbury, Report of the Committee on the Financial Aspects of Corporate

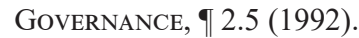

2 Andrei Shleifer \& Robert W. Vishny, A Survey of Corporate Governance, 52 J. Fin. 737, 737 (1997).

3 Jonathan R. Macey, Corporate Governance: Promises Kept, Promises Broken 2 (2008).
} 
corporate law techniques such as the regulation of self-dealing, but also disclosure duties (e.g. in the context of executive compensation and financial accounting).

In putting together the list of authors, the editors hoped to gain broad coverage of different parts of the world, both across the book and within its subjects. We also attempted to illustrate varying methodological approaches pursued by the authors.

\section{A BRIEF INTELLECTUAL HISTORY OF THE FIELD}

Comparative corporate law, including comparative corporate governance, has a rich intellectual history. ${ }^{4}$ As renowned scholar Klaus Hopt has noted, "comparative company law is at once very old and very modern." ${ }^{5}$ The academic focus on comparative corporate law arose in earnest with work that addressed the adoption of US-style securities regulation in Europe and the influence of American company law, as well as research focused on increasing intra-European comparisons due to the harmonization efforts of the European Community. ${ }^{6}$

The 1990s witnessed an increasing interest in comparative corporate law among scholars, including many of the leading corporate law scholars in the United States. Much of the scholarship initially focused on a few jurisdictions, primarily Germany and Japan, as well as the UK. ${ }^{7}$ Furthermore, the study of comparative corporate law quickly morphed into a deeper scholarly engagement with comparative corporate governance. ${ }^{8}$ Major institutes aimed at research on corporate governance, often from interdisciplinary perspectives, were formed by scholars and leading universities around the world. ${ }^{9}$ The scholarly focus on corporate governance was not surprising. As Curtis Milhaupt and Katharina Pistor have noted, corporations are "the most important private actors in a market economy," and "corporate governance is linked to every facet of a country's economic, political, and legal structures."'10

4 For an overview of the intellectual history of comparative law scholarship, see generally Mariana Pargendler, The Rise and Decline of Legal Families, 60 Aм. J. Comp. L. 1043 (2012).

5 Klaus J. Hopt, Comparative Company Law, in The Oxford HandBook of Comparative Law 1161, 1162 (Mathias Reimann \& Reinhard Zimmermann eds., 2006).

6 Id. at $1170-71,1174-76,1179-81$.

7 See, e.g., Bernard S. Black \& John C. Coffee, Hail Britannia? Institutional Investor Behavior Under Limited Regulation, 92 Mich. L. Rev. 1997 (1994); Ronald J. Gilson \& Mark J. Roe, Understanding the Japanese Keiretsu: Overlaps between Corporate Governance and Industrial Organization, 102 YALE L.J. 871 (1993); Curtis J. Milhaupt, A Relational Theory of Japanese Corporate Governance: Contract, Culture, and the Rule of Law, 37 Harv. Int'L L.J. 3 (1996); Mark J. Roe, Some Differences in Company Structure in Germany, Japan and the United States, 102 YALE L.J. 1927 (1993).

8 See, e.g., Klaus J. Hopt, Hideki Kanda, Mark J. Roe, Eddy Wymeersch \& Stefan Prigge (eds.), Comparative Corporate Governance-The State of the Art and Emerging Research (1998).

9 See Klaus J. Hopt, Comparative Corporate Governance: The State of the Art and International Regulation, 59 Aм. J. ComP. L. 1, 3-4 (2011).

10 Curtis J. Milhaupt \& Katharina Pistor, Law and Capitalism: What Corporate Crises Reveal About Legal Systems and Economic Development Around the World 4 (2008); see also Ronald J. Gilson, From Corporate Law to Corporate Governance, in THE OXFoRD HANDBOOK OF Corporate Law and Governance 3, 25 (Jeffrey N. Gordon \& Wolf-Georg Ringe eds. 2018) (stating that the shift from corporate law to corporate governance reflects a legal view of the corporation that is "increasingly complex and dynamic, hand in hand with the increased complexity and dynamics of the capital market, input markets, and product markets that corporations inhabit."). 
The focus on corporate governance became even more pronounced with the publication of an influential series of articles by leading economists - Professors Rafael La Porta, Florencio Lopez-de-Silanes, Andrei Shleifer, Robert W. Vishny and several co-authors-famously referred to as LLSV. As described in Section 3.1 below, the findings of the LLSV line of papers - that is, that shareholder and creditor protection are correlated with capital markets that are larger and deeper, with firms having better access to external financing on better terms, and that countries' economic growth is correlated with their legal origins - were controversial. ${ }^{11}$ While LLSV's initial work on these findings became more nuanced and contextualized over time, their initial claim that common law systems and shareholder protection were critical to market success helped accelerate a burgeoning focus on comparative corporate governance. Importantly for the study of comparative corporate governance, the LLSV claims led to a great deal of scholarship that concretely addressed not just laws on the books in a variety of jurisdictions, but also how corporate governance laws function and are enforced.

By the early 2000s, a vast academic inquiry emerged, particularly at the intersection of law and economics, regarding whether globalization and increasing financial integration were leading to convergence of corporate governance systems, rules, and standards across countries. ${ }^{12}$ The comparative corporate governance inquiry first focused on developed economies, most famously in the collaboration among leading scholars from several developed economies in The Anatomy of Corporate Law. ${ }^{13}$ The authors of the Anatomy argued that "corporate laws everywhere share core features" that are aimed at constraining three kinds of agency conflicts: "conflicts between managers and shareholders, conflicts between controlling and non-controlling shareholders, and conflicts between shareholders and the corporation's other

11 For the initial first two ground-breaking articles, see Rafael La Porta, Florencio Lopez-de-Silanes, Andrei Shleifer \& Robert W. Vishny, Legal Determinants of External Finance, 52 J. FIN. 1131 (1997); Rafael La Porta, Florencio Lopez-de-Silanes, Andrei Shleifer \& Robert W. Vishny, Law and Finance, 106 J. PoL. ECON. 1113, 1145-51 (1998). These articles were followed by a series of other influential papers. See Rafael La Porta, Florencio Lopez-de-Silanes, Andrei Shleifer \& Robert Vishny, Investor Protection and Corporate Governance, 58 J. Fin. Econ. 3 (2000); Rafael La Porta, Florencio Lopez-de-Silanes, Andrei Shleifer \& Robert Vishny, Investor Protection and Corporate Valuation, 57 J. FIN. 1147 (2001); Rafael La Porta, Florencio Lopez-de-Silanes \& Andrei Shleifer, What Works in Securities Laws?, 61 J. Fin. 1 (2006); see also Simeon Djankov, Rafael La Porta, Florencio Lopez-de-Silanes \& Andrei Shleifer, The Law and Economics of Self-Dealing, 88 J. Fin. ECON. 430 (2008).

12 See, e.g., Andreas Fleckner \& Klaus J. Hopt (Eds.), Comparative Corporate Governance: A Functional and International Analysis (2013); JefFrey N. Gordon \& Mark J. Roe, Convergence and Persistence in Corporate Governance (2004); Klaus J. Hopt, Eddy Wymeersch, Hideki Kanda \& Harald Baum (eds.), Corporate Governance in Context: Corporations, States, and Markets in Europe, JAPAN, AND the US (2005); William W. Bratton \& Joseph A. McCahery, Comparative Corporate Governance and the Theory of the Firm: The Case Against Global Cross Reference, 38 Colum. J. Transnat'l L. 213 (1999); John C. Coffee Jr., The Future as History: The Prospects for Global Convergence in Corporate Governance and its Implications, 93 Nw. U. L. Rev. 641, 642 (1999); Ronald J. Gilson, Globalizing Corporate Governance: Convergence of Form or Function, 49 Aм. J. Coмp. L. 329, 336 (2001).

13 See Reinier R. Kraakman et al., The Anatomy of Corporate law: A Comparative and Functional Approach (2004); see also Luca Enriques, The Comparative Anatomy of Corporate Law, 114 Aм. J. Comp. L. 1011, 1011-12 (2004) (correctly predicting that the Anatomy was "certain to become a benchmark and a source of inspiration for comparative corporate governance and corporate law research in the decades to come."). 
contractual counterparties, including particularly creditors and employees."14 The taxonomy of conflicts and the typology of the range of alternative legal responses that are available to address these conflicts in various settings, such as in control transactions, developed in the Anatomy have significantly influenced the approach taken in comparative corporate law scholarship for over a decade.

With the publication of the LLSV literature and the growing convergence debate facilitated by major scholarly works such as the Anatomy, the comparative corporate governance inquiry quickly expanded to other countries and regions as well. ${ }^{15}$ Academic inquiry has been particularly focused on the rapidly developing economies of China, ${ }^{16}$ South Korea, ${ }^{17}$ India,,${ }^{18}$ Brazil,,${ }^{19}$ and to a lesser extent Singapore ${ }^{20}$ and South Africa. Even the Anatomy of Corporate Law expanded its scope to address Brazil in its latest 2017 edition, bringing with it a greater focus on state involvement and state ownership in corporate governance. ${ }^{21}$ And with the growth in comparative corporate governance scholarship, there have been calls for the Anatomy to expand even further to cover other major Asian jurisdictions outside of Japan. ${ }^{22}$

While scholarly literature on comparative corporate governance is flourishing, there are still many important and emerging economies about which there is insufficient literature, at least in English and by legal scholars. ${ }^{23}$ For example, scholars have not yet devoted much attention to

14 John Armour, Henry Hansmann, Reinier Kraakman \& Mariana Pargendler, What is Corporate Law, in Reinier KraAkman et al., The Anatomy of Corporate Law: A Comparative and Functional ApProACH 2 (3d ed. 2017).

15 See, e.g., Dan W. Puchniak, The Derivative Action in Asia: A Complex Reality, 9 BerkeleY Bus. L.J. 1 (2012); Dan W. Puchniak \& Kon Sik Kim, Varieties of Independent Directors in Asia: A Taxonomy, in Independent Directors in Asia: A Historical, Contextual and Comparative Approach (Dan W. Puchniak, Harald Baum \& Luke Nottage eds., 2017).

16 See, e.g., Li-Wen Lin \& Curtis J. Milhaupt, We Are the (National) Champions: Understanding the Mechanisms of State Capitalism in China, 65 Stan. L. Rev. 697 (2013).

17 See, e.g., Hideki Kanda, Kon-Sik Kim and Curtis J. Milhaupt, Transforming Corporate Governance in EAST ASIA (2008).

18 See, e.g., Afra Afsharipour, Corporate Governance Convergence: Lessons from the Indian Experience, 29 Nw. J. INT'L L. \& Bus. 335 (2009); Umakanth Varottil, A Cautionary Tale of the Transplant Effect on Indian Corporate Governance, 21 NAT. L. SCH. Ind. REv. 1 (2009).

${ }_{19}$ See, e.g., Mariana Pargendler, Politics in the Origins: The Making of Corporate Law in Nineteenth Century Brazil, 60 Ам. J. Comp. L. 805 (2012).

${ }_{20}$ See, e.g., Wai Yee Wan, Legal Transplantation of UK-Style Takeover Regulation in Singapore, in Comparative Takeover Regulation: Global and Asian Perspectives (Umakanth Varottil \& Wan Wai Yee eds., 2018); Dan W. Puchniak \& Luh Luh Lan, Independent Directors in Singapore: Puzzling Compliance Requiring Explanation, 65 Aм. J. CoMP. L. 265 (2017).

${ }_{21}$ See KraAKman ET AL., supra note 13. For a comparative analysis of governance challenges in state-owned enterprises, see Curtis J. Milhaupt \& Mariana Pargendler, Governance Challenges of Listed State-Owned Enterprises Around the World: National Experiences and a Framework for Reform, 50 CORNELl INT'L L.J. 473 (2017).

22 See Alan K. Koh \& Samantha S. Tang, The Future of The Anatomy of Corporate Law for Asia: A Forward Looking Critique, 12 Asian J. Comp. L. 197 (2017).

23 For the latest cross-jurisdictional work on corporate governance, see, e.g., JEFFREY N. GORDON \& Wolf-Georg Ringe (eds.), The Oxford Handbook of Corporate Law and Governance (2018) (addressing corporate governance issues in some of the BRIC (Brazil, Russia, India, China) countries, but not many other emerging economies). As Mariana Pargendler explains, comparative analysis of emerging markets lags the "immense literature covering developed countries." The challenges with comparative analysis of emerging markets arise due to the heterogeneity in their histories, politics, economies and legal systems, and the complexities with assessing convergence in corporate governance standards. 
comparative analyses of corporate governance in much of the Middle East (outside of Israel), or in many of the countries in the African continent. Similarly, corporate governance in much of Latin America, outside of Brazil, and some of Asia's most populous countries, such as Indonesia, Pakistan, and Vietnam, remains underexplored by legal academics. ${ }^{24}$

\section{KEY DEBATES}

\subsection{Legal Origins}

While comparative lawyers had long debated the merits and demerits of different legal families, the "legal origins" debate was jumpstarted by a team of economists in $1997 .{ }^{25}$ The authors (LLSV) created relatively crude indices of shareholder (and creditor) protection in a large number of countries based on a survey sent to leading law firms. Based on these indices, they found that common law countries (or "English origin" jurisdictions) provided better investor protection than civil law countries, especially "French origin" countries, with "German origin" and "Scandinavian origin" jurisdictions in the middle. ${ }^{26}$ They found that strong investor protection correlated with certain market indicators, especially the size of the capital market relative to GDP and the degree of dispersion of ownership in the largest publicly traded companies. To deal with endogeneity between measures of market volume and investor protection, the authors used legal origins as instrumental variables, assuming that legal origins are exogenous and influence market outcomes only through better investor protection. ${ }^{27}$

While LLSV were cautious in inferring causation, investor protection could influence ownership structure (and the size of capital markets) in two ways. First, if corporate law protects shareholders against managers, shareholders are more likely to invest. ${ }^{28}$ Second, if corporate law does not prevent the taking of private benefits of control by controlling shareholders, remaining a controlling shareholder is a more attractive financial proposition. ${ }^{29}$ While these are two different pathways, the literature is not always clear on the distinction. ${ }^{30}$

See Mariana Pargendler, Corporate Governance in Emerging Markets, in The OxFORD HANDBOoK OF Corporate LaW AND Governance 735, 737, 750 (2018).

${ }^{24}$ For promising scholarship addressing some of these jurisdictions from comparative perspective, see Carlos Berdejo, Oligarchs, Foreign Powers, and the Oppressed Minority: Regulating Corporate Control in Latin America, 30 Duke J. Comp. \& InT'L L. 1 (2019); Petra Mahy, The Evolution of Company Law in Indonesia: An Exploration of Legal Innovation and Stagnation, 61 Aм. J. Comp. L. 377 (2013); Francisco Reyes, Corporate Governance in Latin America: A Functional Análisis, 39 U. Miami INTER-Am. L. Rev. 207 (2008).

${ }_{25}$ La Porta et al., Legal Determinants, supra note 11; La Porta et al., Law and Finance, supra note 11, at 1145-51; Rafeal La Porta, Florencio Lopez-de-Silanes \& Andrei Shleifer, Corporate Ownership Around the World, 54 J. Fin. 471, 491-98 (1999). See supra note 11 and accompanying text.

26 La Porta et al., Law and Finance, supra note 11, at 1126-34.

27 See infra chs. 2 and 3.

28 E.g., Mark J. Roe, Corporate Law's Limits, 31 J. Legal Stud. 233, 238 (2002).

29 La Porta et al., Investor Protection and Corporate Governance, supra note 11, at 13; Luigi Zingales, Inside Ownership and the Decision to Go Public, 62 Rev. Econ. STud. 425 (1995); Lucian Arye Bebchuk, A Rent-Protection Theory of Corporate Ownership and Control (NBER Working Paper No. 7203, 1999).

30 There is also the possibility of reverse causality, with financial development precipitating investor protection. See Simon Deakin, Prabirjit Sarkar \& Mathias Siems, Is There a Relationship Between 
Not surprisingly, this intrusion into the legal turf by economists resulted in considerable criticism, and sometimes resentment among legal scholars. One point of contention was the crude classification into four legal origins groups, which stands at odds with the depth and nuances of decades of scholarship in comparative law. ${ }^{31}$ Clearly, the diffusion of models and legal transplants around the world permeate the four categories. Even within categories, there is often little unity within the "English origin" group (e.g. between the US on one hand, and the UK and other commonwealth jurisdictions on the other hand). ${ }^{32}$ In addition, the literature ignored the evidence suggesting an absence of meaningful contemporary differences between legal families. ${ }^{33}$ Legal scholars have supplemented the big picture with granular historical case studies, which often do not support the direction of causation implied by LLSV. ${ }^{34}$

Mistakes in the coding posed another, more specific issue. Holger Spamann completely recoded the original index, which resulted in the disappearance of statistically significant results. ${ }^{35}$ Concurrently, the "law and finance" group improved their methods, resulting in an improved and more plausible index. ${ }^{36}$ Other papers in the "law and finance" school found other surprising correlations between legal origins and various economics and social outcomes, some in areas entirely unrelated to corporate law, ranging from government ownership of banks to military conscription. ${ }^{37}$ This raised the question of whether legal origins, even if exogenous because of their ancient roots, are in fact a proxy for political or cultural factors. ${ }^{38}$

Political theories of comparative corporate governance developed parallel to the legal origins literature. A prominent example in the legal literature is Mark Roe's work, which suggested that "social democratic" policies undercut policies that keep managerial agency cost

Shareholder Protection and Stock Market Development?, 3 J.L. FIn. \& AсCт. 115 (2018) (using a panel and Granger causality tests to determine the direction of causation).

31 See, e.g., Detlev Vagts, Comparative Company Law - The New Wave, in Festschrift Für JeAn Nicolas Druey zum 65. Geburtstag 595, 598-99 (Rainer J. Schweizer, Herbert Burkart \& Urs Gasser eds., 2002); Mathias M. Siems, Legal Origins: Reconciling Law \& Finance and Comparative Law, 52 McGiLl L.J. 55, 62-70 (2007) (criticizing the classification of countries).

32 E.g., John Armour \& David A. Skeel, Jr., Who Writes the Rules for Hostile Takeovers, and Why? The Peculiar Divergence of U.S. and U.K. Takeover Regulation, 95 Geo. L.J. 1727 (2007) (discussing the contrasting approaches toward takeover law); Christopher M. Bruner, Power and Purpose in the “Anglo-American" Corporation, 50 VA. J. INT'L L. 579, 593-611 (2010) (comparing shareholder and board centrism in the two jurisdictions).

33 E.g. Mark J. Roe, Legal Origins Politics, and Modern Stock Markets, 120 Harv. L. Rev. 460, 475-76 (2006) (discussing the erosion of differences between civil law and common law); Holger Spamann, Contemporary Legal Transplants: Legal Families and the Diffusion of (Corporate) Law, 2009 BYU L. Rev. 1813, 1814-15 (2009) ("Some of the most sophisticated comparative lawyers assert that there are few if any relevant differences between common and civil law today.").

34 E.g., Brian R. ChefFins, Corporate Ownership and Control: British Business Transformed (2008); John C. Coffee Jr., The Rise of Dispersed Ownership: The Roles of Law and the State in the Separation of Ownership and Control, 111 YaLE L.J. 1 (2001); Carsten Gerner-Beuerle, Law and Finance in Emerging Economies: Germany and Britain 1800-1913, 80 Modern L. Rev. 263 (2017).

35 Holger Spamann, The “Antidirector Rights Index” Revisited, 23 Rev. Fin. STud. 467 (2009).

36 Djankov et al., supra note 11.

37 Rafael La Porta, Florencio Lopez-de-Silanes \& Andrei Shleifer, The Economic Consequences of Legal Origins, 46 J. ECON. Lit. 285, 292 (2008).

38 Economists have continued to test LLSV's theories with more sophisticated econometric methods. See, e.g., Glauco De Vita, Chengchun Li \& Yun Luo, Legal Origin and Financial Development: A Propensity Score Matching Analysis, forthcoming InT'L J. Fin. ECon. (finding that German legal origin predicts financial development). 
in check. A key example was monitoring by the board, which is inhibited by German codetermination in the view of its critics. ${ }^{39}$ Roe proposed that the rise of these types of policies was caused by the economic devastation in Europe and Japan during the first half of the twentieth century, which dealt a lasting blow to capital markets and thus put a greater emphasis on protecting what was left to individuals, namely their human capital in their role as employees. ${ }^{40}$

Other scholars have put forward additional complex political explanations. ${ }^{41}$ To cite a prominent example, Gourevitch and Shinn have explained diverging corporate governance outcomes as the outcomes of coalitions between three groups-insiders of the firm, capital, and labor. Which system emerges depends on which coalition forms and dominates in a particular country and time period. For example, workers may align with blockholders to form a "stakeholder model," or they may align with outside investors to form a "transparency coalition" if they have significant pension savings in the stock market. ${ }^{42}$ Differences in the political system may play a role (for example, the distinction between majoritarian and proportional representation systems), which result in different electoral coalitions. ${ }^{43}$

Two caveats should be made about these debates. First, ownership structures have undergone considerable change in recent years, with the remarkable rise of institutional ownership in many jurisdictions eroding some of the classic differences. ${ }^{44}$ Second, political explanations tend to focus on Western democracies and Japan, and tend not to look toward the developing world. In contrast, legal origins studies include developing countries in their datasets. It is plausible that the differences picked up in the literature are not necessarily differences in the legal systems between European countries, but rather divergences in colonial or post-colonial transplantation between English and other colonies. ${ }^{45}$ Laws typically are not transplanted within their full social context, which is why they often do not operate effectively in the recipient country. ${ }^{46}$ Consequently, legal origins may reflect different styles of major powers in imposing their legal system or merging it with local traditions. Moreover, the influence of legal families likely persists not because of historical events, but rather because of ongoing dif-

39 Mark J. Roe, Political Determinants of Corporate Governance 29-37 (2003); Roe, supra note 28 , at 253-69.

40 Roe, supra note 33.

41 John W. Cioffi, Public Law And Private Power 9 (2010) (suggesting that Social Democrats allied themselves with outside investor interests in Germany in the early 2000s); PEPPER D. CULPEPPER, Quiet Politics And Business Power Corporate Control In Europe And Japan (2011) (emphasizing how corporate governance reforms are influenced by their salience among the electorate). For a useful overview of recent political theories of corporate governance, see Manabu Matsunaka, Politics of Japanese Corporate Governance Reform: Politicians Do Matter, 15 BeRKeley Bus. L.J. 154, 156-61 (2018).

42 Peter Alexis Gourevitch \& James J. Shinn, Political Power and Corporate Control 9 (2005).

43 Marco Pagano \& Paolo F. Volpin, The Political Economy of Corporate Governance, 95 Am. ECON. REV. 1005 (2005).

44 See Adriana de La Cruz, Alejandra Medina \& Yung Tang, Owners of the World's Listed Companies, OECD Capital Market Series (2019), www.oecd.org/corporate/Owners-of-the-Worlds -Listed-Companies.htm; Gur Aminadav \& Elias Papaioannou, Corporate Control Around the World, 75 J. FIN. 1191 (2020).

45 Daniel M. Klerman, Paul G. Mahoney, Holger Spamann \& Mark I. Weinstein, Legal Origin or Colonial History?, 3 J. Legal Analysis 379 (2011).

46 Daniel Berkowitz, Katharina Pistor \& Jean-François Richard, The Transplant Effect, 51 Aм. J. Comp. L. 163, 189 (2003). 
fusion from origin to recipient countries due to familiarity with the language, legal cooperation and development aid, and academic exchanges. ${ }^{47}$

\subsection{Convergence}

A significant trend in corporate governance prevalent throughout this book is convergence. Scholars became increasingly cognizant of converging trends between jurisdictions during the late 1990s and early 2000s, which matched contemporary debates about economic globalization. ${ }^{48}$ In a provocative article, Hansmann and Kraakman predicted an "End of History for Corporate Law" based on an Anglo-American model of shareholder wealth maximization and stronger rights of outside investors. ${ }^{49}$ While there were several factors pushing toward convergence, arguably the most important one was the perceived efficiency of this model. Firms run according to a more efficient model will eventually outcompete others in globalizing capital and product markets. By extension, countries with better corporate law will be more successful, forcing others to adapt.

While there seems to be consensus that there was some level of convergence, the theory raises several questions. First, it is not particularly specific about which policies will prevail, as there is no single Anglo-Saxon or common law model. ${ }^{50}$ Second, there are numerous factors that can help explain the persistence of existing laws and corporate governance practices. First, path dependence theory suggests that powerful interest groups will oppose convergence because they obtain rents from the status quo. ${ }^{51}$ For example, if controlling shareholders and labor manage to maintain a coalition domestically, the country would have to be relatively open to competition from the outside and competitive pressures would have to be relatively strong to overcome internal opposition to convergence.

Second, it is not obvious that a single model will be optimal for all countries. Different countries might specialize in the production of different goods and services, for which different corporate governance models will be suited. For example, developed countries have sometimes been classified into "arm's length finance" jurisdictions, which rely on capital markets, and "insider finance" jurisdictions, where firms refinance mainly through blockholders and banks. ${ }^{52}$ The "varieties of capitalism" literature extends this framework by suggesting institutional complementarities with other aspects of economic regulation. ${ }^{53}$ In this view, bank-based financial systems provide a better match, for example, to labor systems relying on a greater

\footnotetext{
47 Spamann, supra note 33, at 1844-51.

48 Alan Dignam \& Michael Galanis, The Globalization of Corporate Governance 110-43 (2009); Mathias M. Siems, Convergence in Shareholder Law 226-27 (2008).

49 Henry Hansmann \& Reinier Kraakman, The End of History for Corporate Law, 89 Geo. L.J. 439, 443 (2001).

50 See supra note 32 and accompanying text.

51 E.g., Lucian Arye Bebchuk \& Mark J. Roe, A Theory of Path Dependence in Corporate Ownership and Governance, 52 StAn. L. Rev. 127, 142-53 (1999).

52 E.g., Erik Berglöf, A Note on the Typology of Financial Systems, in Comparative Corporate Governance 151, 159-64 (Klaus J. Hopt \& Eddy Wymeersch eds., 1997); Dignam \& Galanis, supra note 48, at 64; Christian Leuz, Different Approaches to Corporate Reporting Regulation: How Jurisdictions Differ and Why, 40 ACCT. \& Bus. RES. 229, 236-37 (2010).

53 See generally Peter A. Hall \& David Soskice, An Introduction to Varieties of Capitalism, in VARIETIES OF CAPITAlism 1, 8-9 (Peter A. Hall \& David Soskice eds., 2001); Milhaupt \& Pistor, supra note 10 .
} 
role for long-term commitment of workers and the creation of specific human capital. ${ }^{54}$ Other scholars have emphasized cultural explanations of persistent corporate governance differences, which may help entrench both economic patterns and legal path dependences. ${ }^{55}$ Thus, countries could succeed internationally by adopting a production model or producing goods and services that match its "variety of capitalism" or culture.

Although the question of convergence is ultimately an empirical one, it is by no means clear that the end point will be an investor rights or shareholder primacy equilibrium. It is equally plausible that we will see a modest level of convergence, and the persistence of variations between countries pursing different economic strategies. The chapters in this book demonstrate considerable borrowing of ideas. Arguably, convergence was strong until the 2008/09 financial crisis, and even afterwards to some extent. The verdict about the 2010 s will likely be more mixed. In some areas, we see increasing convergence along the lines predicted by Hansmann and Kraakman, for example shareholder "say on pay" on executive compensation. ${ }^{56}$ In other areas, we appear to see convergence, but in a different direction. Most strikingly, during the past years there have been increasing concerns about sustainability and a greater push toward a corporate purpose that deviates from shareholder wealth maximization. ESG issues have very much come to the forefront of the debate in both developed and developing economies. ${ }^{57}$

\section{THE BOOK'S PERSPECTIVE}

\subsection{Perennial Debates}

This book begins with a section on perennial debates in comparative corporate governance. The first two chapters address the methods used in comparative corporate law scholarship. During the past three decades, the volume of comparative law scholarship has grown in general, and the methods have shifted from the traditional functionalism represented by venerable treatises ${ }^{58}$ toward greater methodological variation. ${ }^{59}$ Specifically in corporate law, a contributing factor may have been the increased interest in comparative corporate law in the United States, where mainstream legal scholarship has, over the decades, absorbed various interdisciplinary methods. ${ }^{60}$ In corporate law, an economic perspective dominates, and the field was further invigorated by a broader law and finance perspective, with finance scholars following the footsteps of LLSV in incorporating legal issues into their models. Not surprisingly, comparative scholarship also often takes an economic view and emphasizes the

\footnotetext{
54 E.g., Dignam \& GALANis, supra note 48, at 75-76.

55 Amir N. Licht, The Mother of All Path Dependencies: Toward a Cross-Cultural Theory of Corporate Governance Systems, 26 DEL. J. CoRP. L. 147 (2001).

56 See infra ch. 12.

57 See infra ch. 5.

58 E.g., Konrad Zweigert \& Hein Kötz, An Introduction to Comparative Law (English Translation 1998).

59 E.g., Mathias M. Siems, Comparative Law (2d ed. 2018).

60 E.g., Nuno Garoupa \& Thomas S. Ulen, The Market for Legal Innovation: Law and Economics in Europe and the United States, 59 Ala. L. REv. 1555, 1568-78 (2008); Kristoffel Grechenig \& Martin Gelter, The Transatlantic Divergence in Legal Thought: American Law and Economics vs. German Doctrinalism, 31 Hastings InT'L \& Comp. L. Rev. 295, 328-30 (2008).
} 
incentives set by law, as well as the interest groups whose economic interests have shaped the law across jurisdictions. ${ }^{61}$

In his chapter, Christopher Bruner tackles the difficult question of methodology. He contrasts functionalism with contextualism, which emphasizes jurisdictional differences. Contextualists often assume a high degree of difference that cannot be eliminated because of the difficulties involved in legal transplantation. However, contextualism often fails to provide a theory for differences. Within law and economics, there is a major functionalist current, but the shift from "corporate law" to "corporate governance" in the literature has brought a broader set of cultural, political and economic issues into the debate. A major difficulty in comparison is the fact that corporate law and governance do not have the same function in each jurisdiction, but are part of a larger set of institutional complementarities. Choice of method is thus typically a function of the intended audience, placing a premium on methodological self-awareness and careful calibration of one's claims.

Maribel Sáez and María Gutiérrez highlight the specific contributions of law and economics. They suggest that this field has been rebranded repeatedly, moving from "comparative corporate law" through "comparative corporate governance" to "law and finance" and finally to the "theory and empirics of comparative corporate law." Corporate law scholarship started with the doctrinal "Continental European" approach to law, which looks at the legal system purely hermeneutically and from the inside. In the authors' views, this limited approach has consequences for the development of the law, e.g. by permitting clearly deficient rules to persist because of their good fit with the existing system, and by ignoring the enforcement problems of the law on the books. Comparative company law went beyond a mere description of foreign law, often adopting English as its lingua franca. Comparative corporate governance then infused economic thinking into the field, by focusing on solutions to agency problems. "Law and finance" subsequently added a causal link between legal origins and good corporate law on the one hand, and good economic outcomes on the other hand. Finally, more recent literature either provides a more theoretically informed investigation of domestic laws or investigates specific causal claims empirically.

Vikramaditya Khanna provides a detailed survey of the law and finance literature and its implications for economic development, surveying the voluminous empirical literature. $\mathrm{He}$ first tackles the question of causation - does strong investor protection facilitate economic growth and developed capital markets, or do interest groups with a stake in the market lobby for strong corporate law? In summary, he suggests that "there is good evidence for a growth to law causation story and some evidence for a law to growth causation story." The chapter also considers the evidence that too much investor protection may inhibit investment and growth. The chapter additionally surveys studies that explore what specific aspects of corporate law matter, such as boards or Delaware incorporation within the United States. Internationally, the entrenchment of the board is of lesser concern (given more concentrated ownership structures), but enforcement, disclosure and the rights of outside investors play a considerable role. Finally, the chapter touches upon the corporate purpose debate and recognizes that corporate law may contribute to developments in ways going beyond those conventionally understood if we take the impact on stakeholders into account.

${ }^{61}$ See, e.g., ANATOMy of CoRporate Law, supra notes 13 and 14 (taking an economic approach in the guise of a functional approach). 
In recent years, the debate about the proper role of the corporation in law and society has often been described as being about "corporate purpose" or as the "shareholder-stakeholder" debate, but its ancient roots go back over a century. Writing in 1917, German industrialist and politician Walther Rathenau expressed deep concern about the role of short-term shareholders who expected firms to produce returns at the expense of long-term development and the public interest, ${ }^{62}$ which triggered a posthumous debate about his claims during the late 1920 s. $^{63}$ The Berle-Dodd debate of 1931 in the US prefigured many of the arguments of subsequent decades, and serves as a template for recurring corporate purpose debates to this day. ${ }^{64}$ The "corporate purpose" debate has again gained traction in recent years, as the Business Roundtable in the US in 2019 abandoned a shareholder primacy conception of the corporation in favor of a stakeholder conception. ${ }^{65}$

Barnali Choudhury and Martin Petrin tackle the corporate purpose debate with an emphasis on the UK and the US. The chapter surveys discussions on both corporate purpose and short-termism. While directors have the freedom to consider interests besides those of shareholders, as a matter of practice most firms continue to focus on a narrow corporate purpose. In the view of the authors, this narrow vision is conducive to short-termist corporate activities. Thus, the chapter argues that US and UK firms should attempt to advance from a shareholder ideology to a broader perspective. The authors suggest several reforms in corporate and securities law that would facilitate such a development.

Cynthia Williams' chapter reviews developments relating to CSR and ESG (environmental, social and governance) issues. It explores the increasing emphasis of institutional investors, including index funds, on ESG data. The author argues that part of the reason that institutional investors are emphasizing ESG is because of younger investors' increasing interest in topics such as climate change and economic inequality, and because the connection between companies' better management of ESG issues and better financial performance is becoming well-established. Regarding CSR, the increasing importance can be seen in the activities of multi-stakeholder collaborations establishing voluntary standards for CSR in many industries, and in the actions of international organizations such as the United Nations establishing standards for companies' international human rights obligations or goals for Sustainable Development. As to differences between countries in the importance given to CSR or the voluntary versus mandatory nature of the field, Williams surveys a number of explanations, including the possibility that countries with a less developed social welfare systems may require a greater degree of voluntary CSR to maintain the legitimacy of the corporate governance system. However, countries with a strong stakeholder orientation in corporate law tend to score better on sustainability indices, showing the potential importance of current discussions of shifts in the United States from shareholder primacy to stakeholder governance. Ownership structures and the predominant types of investors appear to have an impact on sustainability

\footnotetext{
62 Walther Rathenau, Vom Aktienwesen: Eine Geschäftliche Betrachtung (1917).

63 See Fritz Haussmann, Vom Aktienwesen Und vom Aktienrecht 20 (1928).

64 Adolf A. Berle, Corporate Powers as Powers in Trust, 44 Harv. L. Rev. 1049 (1931); E. Merrick Dodd, Jr., For Whom Are Corporate Managers Trustees?, 45 Harv. L. Rev. 1145 (1932); A. A. Berle, Jr., For Whom Corporate Managers Are Trustees: A Note, 45 HaRv. L. Rev. 1365 (1931).

65 Business Roundtable, Statement on the Purpose of the Corporation (2019), available at https://s3.amazonaws.com/brt.org/BRT-StatementonthePurposeofaCorporationOctober2020.pdf. But see Lucian A. Bebchuk \& Roberto Tallarita, The Illusory Promise of Stakeholder Governance, 106 Cornell L. Rev. 91, 124-39 (2020) (criticizing the statement).
} 
outcomes as well. In addition, CSR-oriented disclosure requirements create incentives for firms to pursue and highlight socially responsible corporate activities.

\subsection{The Board}

Part II of the book turns to substantive topics in corporate governance, starting with the central players in internal corporate governance in most jurisdictions: the board of directors. National legislation provides important differences in the structure of the board, with the US one-tier model and the German two-tier structure often seen as exemplars. Scholars argue, however, that "board practices can blur the distinction between the two structures." ${ }^{66}$ What is clear in most jurisdictions is that for publicly traded corporations, the ultimate management power is embedded in the board of directors, increasingly dominated by independent directors. ${ }^{67}$ Not only do boards have ultimate managerial power, but the board of the modern public company is vested with a monitoring or oversight role. The conception of public company boards as a monitoring board with the primary function of monitoring the selection and supervision of the corporation's executives was most famously articulated in Professor Melvin Eisenberg's classic work. ${ }^{68}$ Since first articulated by Professor Eisenberg, the board's monitoring role has grown over time. ${ }^{69}$ The chapters in this section first examine the structure and composition of the board of directors, before turning to issues that go to the heart of board responsibilities, including the exercise of fiduciary duties and the board's monitoring and oversight roles, particularly in risk management, executive compensation, and disclosure.

Klaus Hopt and Patrick Leyens explore the structure of the board of directors with a focus on the two most commonly used board models in corporate law: the one-tier board with a significant number of non-executive directors, and the two-tier structure where non-executive directors are members of a supervisory board while executives directors compose the management board. Hopt and Leyens argue that rather than settling on a particular board model, the law should allow corporations flexibility in the choice of a board model. They stress that focusing on the specific governance strategies available in a variety of situations, for example takeovers or related party transactions, demonstrates that boards can address the types of agency problems that arise in corporate governance in similar ways, regardless of the choice of board model. Hopt and Leyens focus on three sample jurisdictions - the US, the UK, and Germanyto show that different board models can accommodate the agency problems that commonly arise in publicly listed corporations. They then complicate this argument by considering how the board as an institution can be used to hold the corporation accountable to non-shareholders, particularly employee stakeholders. As they show, it is only with employee-codetermination as a governance strategy that one needs a two-tier board model.

Jean $d u$ Plessis's chapter provides a broad survey of different types of board structures used around the world, focusing on similarities and deviations in jurisdictions where a unitary

\footnotetext{
66 John Armour, Luca Enriques, Henry Hansmann \& Reinier Kraakman, The Basic Governance Structure; The Interests of Shareholders as a Class, in ANATOMY, supra note 14, at 49, 51.

67 See id. at 50, 62-65.

68 Melvin A. Eisenberg, The Structure of the Corporation: A Legal Analysis (1976).

${ }^{69}$ See Renee B. Adams, Benjamin E. Hermalin \& Michael S. Weisbach, The Role of the Board in Corporate Governance: A Conceptual Framework and Survey, 48 J. Econ. LiT. 58, 64-65 (2010); Ronald J. Gilson \& Jeffrey N. Gordon, Board 3.0: An Introduction, 74 Bus. LAw. 351, 355-58 (2019).
} 
board, a two-tier board, or an auditor board structure are required. The chapter discusses the nuances of how even similar structures, such as the two-tier board, are implemented differently in different jurisdictions. Taking a broad perspective, the chapter then explores the nuances of board composition rules in various jurisdictions, including the UK, Germany, the Netherlands, China, and Japan. Du Plessis closes by providing a historical perspective on board composition and board structure, focusing primarily on early initiatives, namely the 1971 Canadian Dickerson Report, the EU Draft Fifth Directive on Company Law, the European Company, and the 1977 UK Bullock Report. He argues that the board governance recommendations in these initiatives continue to remain relevant today.

Darren Rosenblum's chapter discusses gender diversity, a pressing issue in board governance and composition today. The chapter provides a comparative account of regulatory efforts to implement sex diversity on boards. After exploring the history of corporate board quotas for women, the chapter addresses the types of quotas and intervention models used in different jurisdictions, from the hard statutory mandates of Norway to the soft quotas and disclosure mandates in some common law jurisdictions, including the UK and Canada. The chapter analyzes the policy challenges raised by current diversity regimes, and what such challenges may mean for future legislation and policy interventions as diversity continues to play a prominent role in corporate governance debates.

Turning from board structure and composition to board duties and responsibilities, the next set of chapters in this part address convergence in the specific duties and functions of the board. Marco Corradi and Geneviève Helleringer examine the duty of loyalty-encompassing both rules that govern self-dealing and corporate opportunity transactions-from a comparative perspective. The chapter begins by comparing the approach to regulating self-dealing and related party transactions under both common law (namely the US and UK) and civil law regimes (focusing on continental Europe). It then turns to the legal development of corporate opportunity rules, and contrasts the approach to corporate opportunities under US law with the less-developed jurisprudence on corporate opportunities in civil law jurisdictions. They note the tensions between the evolution of the law governing self-dealing transactions at the European level, and the lack of harmonization on rules addressing corporate opportunities and its continuing divergences across EU jurisdictions.

Carsten Gerner-Beuerle examines the diffusion and convergence of the duty of care, a fundamental fiduciary responsibility of the board, and its "judicial offshoot," the business judgement rule, whereby courts refrain from reviewing good faith business decisions. The chapter begins by demonstrating how the duty of care and the business judgment rule are similarly formulated across jurisdictions, examining both common law and European civil law countries. Through a comparison of the US and UK approaches, the chapter reveals that even if the formulation of a legal rule may differ, as with the business judgement standard in the UK, the operation of such a rule may be the same. In the tradition of the legal transplants literature, the chapter then compares the application of the Delaware business judgment rule with its German counterpart to show that even similarly formulated rules differ in actual operation because of underlying local norms and narratives.

A central function of the modern public company board is its monitoring and oversight role. Virginia Harper Ho's chapter analyzes risk oversight and risk management as core elements of the board's monitoring role. The chapter draws on examples from both international guidance and different legal systems, including the US, the UK, continental Europe, and China, as well as international standards, to explain the basic mechanisms of risk oversight, 
risk management and compliance. The chapter argues that across jurisdictions, the fiduciary duties of care and loyalty are used to hold boards accountable for carrying out their monitoring role. Going beyond an analysis of fiduciary duties, the chapter proposes that the board's increasingly complex risk management and oversight responsibilities are now derived from and impacted by multiple sources, including other regulatory regimes, market actors and institutions, that have expanded risk regulation. The chapter thus concludes by identifying the key sources of corporate risk oversight that inform and complement the role of the corporate board in risk management.

Examining the convergence-divergence debate through the lens of executive compensation, Li-Wen Lin's chapter examines the legal regime on executive compensation in six jurisdictions, including the United States, the United Kingdom, Germany, Japan, India, and China. Executive compensation has long been viewed as within the central powers of the board, but Lin's chapter reveals the extent to which, for publicly traded companies in many jurisdictions, the board of directors is no longer the only body with power over executive compensation decisions. The chapter shows that not only have the legal rules restricting the board's power over executive pay begun to diverge in Western countries, but also that directors' power over executive pay varies widely when one assesses the legal regime in leading Asian jurisdictions such as Japan, India, and China.

A crucial function of the board of directors is the oversight of financial disclosure, with audit committees becoming ubiquitous as standing committees of public company boards. Financial disclosure to investors necessarily depends on accounting standards. Thus, Martin Gelter's chapter grapples with the question of convergence and path dependence in accounting laws and standards. Gelter argues that while accounting appears to have undergone international convergence, at least in the goals of the dominant accounting standards, there remains considerable persistence and divergence when one compares accounting standards in the US and the EU member states. Gelter explains this persistence by turning to the theory of path dependence. He exposes how the divergent interests of the accounting industry, a key interest group in accounting, explains the lack of convergence in accounting standards.

\subsection{Shareholders}

As we note above, much of corporate governance concerns itself with balancing conflicts and power between shareholders and managers, as well as among shareholders, namely controlling and non-controlling shareholders. Shareholders are not a monolithic group, ranging from the state, hedge funds, and institutional investors to family groups and individuals. Furthermore, the past two decades have experienced significant changes in capital market structures around the world, resulting in a reassessment of shareholder power and participation in corporate governance, and debates about the degree to which the law can and should provide shareholders with a voice and facilitate greater shareholder protection. ${ }^{70}$ The chapters in Part III of the book explore the makeup and power of contemporary shareholders, seeking to address both the increasing significance of institutional investors and transformations in shareholder power,

70 For a series of chapters on shareholder categories, shifts in shareholder power and international perspectives on shareholder power, see Jennifer G. Hill \& Randall S. Thomas, Research Handbook ON SHAReHOLder Power (2015). 
rights and duties. Given the prevalence of concentrated shareholding around the globe, several chapters address the rights, powers and duties of both controlling and minority shareholders.

Sofie Cools analyzes the transformation of shareholder power by comparing the use of shareholder proposals by shareholders of US public companies with the relative lack of such proposals in Europe. Focusing on Delaware, France, Germany, Belgium, and the Netherlands, the chapter begins with a concise historical account of the evolution of shareholders' substantive powers and initiative powers. Using a functional approach, the chapter then dives into assessing each set of shareholder powers in detail, and argues that private ordering through shareholder power proposals in US companies is largely closing the gap in substantive shareholder power that has existed between the United States and Europe. The chapter also casts doubt on empirical comparisons of the frequency of shareholder proposals in the US and Europe by showing how two important factors - differences in ownership structures and the goals of shareholder proposals in the US - complicate such comparisons.

Turning to the dramatic increase in institutional investors around the globe, Assaf Hamdani and Sharon Hannes analyze the governance implications of this rise against the background of the growing influence of activist hedge funds. Using examples from a variety of jurisdictions, they argue that for widely held companies, institutional investors can determine the outcome of shareholder votes, including director elections. Nevertheless, they point out that even for companies with dispersed ownership, country-specific regulations, political sentiments, and social norms will impact the extent to which institutional investors will actually wield their rising power. The chapter then turns to the limited ability of institutional investors to influence governance in jurisdictions with predominantly controlled companies and considers the potential for institutional investors to become powerful in countries, such as Israel, experiencing a shift from concentrated to dispersed ownership of publicly listed corporations.

Gaia Balp and Marco Ventoruzzo focus on the rules governing the duties of controlling shareholders to minority shareholders in three jurisdictions: the US, Germany, and Italy. The chapter argues that despite differences in the specific laws and enforcement mechanisms used to address the duties of controlling shareholders, the principles and conceptual goals across these jurisdictions are functionally quite similar. To support their argument, the chapter examines controllers' duties in a variety of situations that present universal conflicts in controlled companies - related party transactions, sale of a control stake and access to privileged information. They demonstrate that, irrespective of the specific rules and enforcement tools used in each of these situations, loyalty underpins the standards and rules for controllers' conduct. Nevertheless, the chapter recognizes that differences among these jurisdictions in the involvement of the courts and in ex-ante versus ex-post legal regimes may impact the actual level of minority investor protection.

Minority shareholders are not homogeneous, both within and across jurisdictions, in their makeup, goals, and actions. Umakanth Varottil explores the implications of the increasing heterogeneity of minority shareholders. The chapter argues that the expanding schism among minority shareholders creates agency problems among types of minority shareholders, allowing one type of minority shareholder to affect the interests of others. The chapter thus addresses and expands on existing calls for legal rules that restrain minority shareholder behavior. ${ }^{71}$ To further its claims, the chapter begins by recounting the evolution of the identity of minority

${ }_{71}$ See. e.g., Iman Anabtawi \& Lynn A. Stout, Fiduciary Duties for Activist Shareholders, 60 STAN. L. REv. 1255 (2008). 
shareholders, focusing on the rise of institutional investors in the global stock markets. It then turns to analyzing the goals and actions of two types of institutional investors-activist hedge funds and passive funds - to show the potential conflicts among these shareholders. The chapter ends by discussing from a comparative lens the legal tools, such as fiduciary duties and stewardship responsibilities, available to address such conflicts.

Sang Yop Kang addresses controlling shareholder power in two types of scenarios: controlling shareholders in corporate groups versus single corporations operating various business lines. While these two types of business may functionally operate in a similar manner, Kang explores the differences that arise in controllers' behaviors in three contexts: risk-sharing (cash-flow stabilization), control/voting leverage, and tunneling. The theoretical prism used by Kang in analyzing these different contexts suggests that to increase their power and opportunities, controllers may be more inclined to establish corporate groups rather than single corporations with different business lines (although controllers' preference for the corporate-group form is not always absolute).

\subsection{Enforcement of Corporate Law}

Directors' and shareholders' duties would be irrelevant in practice if they were not enforceable. Not surprisingly, there are big international differences in this regard. ${ }^{72}$ According to the conventional wisdom in comparative corporate law, the US is the country where corporate law (as well as securities laws) are most vigorously enforced..$^{73}$ This is in part due to the existence of an entrepreneurial plaintiff bar, which exists thanks to various institutional circumstances, not the least the American rule in civil procedure (where each party pays their own cost) and the possibility of contingency fees, which induces plaintiff attorneys to bring class actions as well as derivative suits. ${ }^{74}$ There are other jurisdictions where litigation has become common, for example Japan in the area of derivative litigation, ${ }^{75}$ as well as Canada, Australia, and Israel

72 See, e.g., Harald Baum \& Dan W. Puchniak, The Derivative Action: An Economic, Historical and Practice-Oriented Approach, in The Derivative Action in Asia 1 (Harald Baum \& Dan W. Puchniak eds., 2013); Mathias M. Siems, Private Enforcement of Directors' Duties, in Collective Actions 93 (Stefan Wrbka, Steven van Uytsel \& Mathias Siems eds., 2012); Brian R. Cheffins \& Bernard S. Black, Outside Director Liability Across Countries, 84 Tex. L. Rev. 1385 (2006); Martin Gelter, Why do Shareholder Derivative Suits Remain Rare in Continental Europe, 37 Brook. J. InT'L L. 844 (2012); Puchniak, supra note 15, at 1.

73 On regulators, see, e.g., Klaus J. Hopt, Comparative Corporate Governance: The State of the Art and International Regulation, in COMPARATIVE CORPORATE GovernANCE, supra note 12, at 3, 87-90. On the role of litigation, see, e.g., Bruner, supra note 32, at 609-11 (contrasting the greater reliance of US law on litigation with the ability of UK shareholders to remove directors); Alessio M. Pacces, Controlling the Corporate Controller's Misbehavior, 11 J. CoRP. L. STUD. 177, $203-04$ (2011) (discussing enforcement of self-dealing law by the Delaware courts).

74 See, e.g., John C. Coffee, Jr., The Globalization of Entrepreneurial Litigation: Law, Culture, and Incentives, 165 U. PA. L. REv. 1895, 1917 (2017) (describing institutional factors favoring entrepreneurial litigation in the US and how it spreads elsewhere).

75 Dan W. Puchniak \& Masafumi Nakahigashi, Japan's Love for Derivative Actions: Irrational Behavior and Non-Economic Motives as Rational Explanations for Shareholder Litigation, 45 VAND. J. Transnat'l L. 1 (2012); Mark D. West, Why Shareholders Sue: The Evidence from Japan, 30 J. Legal STUD. 351 (2001). 
in securities law. ${ }^{76}$ In all cases, cost rules have become favorable to lawsuits. The other aspect of enforcement is the public side, i.e. enforcement by securities regulators, which relies largely on financial endowment and qualified staff. ${ }^{77}$

The chapters in the book tackle enforcement from two perspectives. Pierre-Henri Conac's chapter looks specifically at the enforcement of corporate governance rules, including corporate governance codes. Taking a broad perspective, Conac looks at factors facilitating private shareholder litigation, as well as enforcement by regulators, focusing mainly on European jurisdictions, the United States, and Brazil. Among other factors, this chapter explores stock exchanges (which have shed their public nature in recent decades and now compete for listings) as enforcers considered intermediate between public and private mechanisms. The chapter argues that private enforcement should be the main legal technique for enforcement, but that public regulation should serve as a stopgap that remedies the deficiencies of the private model.

Alan Koh and Samantha Tang restrict their analysis to private litigation in corporate law and exclude securities law aspects. Their chapter provides a highly detailed taxonomy of the various types of lawsuits and their functions in the Anglo-Commonwealth jurisdictions (UK, Australia, Singapore, Hong Kong, New Zealand), the US, Germany, and Japan. The chapter considers key factors furthering and limiting such suits, including cost structure, length of the litigation, and possible outcomes. Besides derivative litigation, which involves remedies from which the company itself benefits, the chapter looks very closely at direct suits, which have received less attention in the literature. The taxonomy encompasses monetary and non-monetary remedies, and looks at oppression and withdrawal, appraisal rights, injunctions, as well as litigation challenging the validity of shareholder decisions.

\subsection{M\&A}

The final two chapters of the book turn their attention to assessing corporate governance in the specific context of mergers and acquisitions (M\&A), including those involving the management of the corporation. M\&A transactions - i.e. the transfer of control and ownership of a business as an entirety - are among the most significant transactions undertaken by a firm. Such transactions also provide opportunities and incentives for conflicts of interests between and among the board, officers, and shareholders. ${ }^{78}$ Accordingly, the legal system in many jurisdictions focuses on the balance of power in M\&A transactions so as to both facilitate M\&A transactions and constrain, or manage, the types of conflicts that can arise. ${ }^{79}$ Thus, corporate governance is at the center of the regulation of M\&A.

The US and UK are the two most active markets for M\&A transactions, particularly takeovers involving publicly traded firms. And to a large extent their regulatory approaches to addressing conflicts in M\&A have had a significant impact on M\&A regimes in other jurisdic-

76 E.g., Martin Gelter, Global Securities Litigation and Enforcement, in Global SECURITIES Litigation And Enforcement 3, 39 (Pierre-Henri Conac \& Martin Gelter eds., 2019).

77 See Howell E. Jackson \& Mark J. Roe, Public and Private Enforcement of Securities Laws: Resource-Based Evidence, 93 J. FIN. ECON. 207 (2009).

78 See John C. Coates Jr., Mergers, Acquisitions, and Restructurings: Types, Regulation, and Patterns of Practice, in OxFORD HANDBOOK, supra note 10, at 570, 576-82.

79 See Paul Davies, Klaus Hopt \& Wolf-Georg Ringe, Control Transactions, in AnATomy, supra note 14 , at $205,207-11$. 
tions. ${ }^{80}$ Thus, both of the chapters in this section of the book focus on a comparative analysis of the US and UK.

Afra Afsharipour considers how corporate governance concerns are reflected in the approach to regulating friendly takeover transactions in the US and UK. The chapter argues that, with respect to friendly takeovers, the two jurisdictions address corporate governance concerns and the balance of power between the board of directors and shareholders in increasingly divergent ways. The chapter discusses how the UK restrains director power in friendly M\&A deals, including recent rules that constrain the power of directors to negotiate deal protection mechanisms. The chapter compares the UK model with that adopted in the US, which provides wide latitude to directors to negotiate and design M\&A deals and, due to recent changes to Delaware jurisprudence, provides little opportunity for shareholders to check management conflicts through litigation. The chapter concludes by assessing the extent to which trajectory of US and UK experiences with addressing corporate governance in friendly takeovers demonstrates the important pull of path dependence in the design of corporate governance rules.

Turning to director and officer fiduciary duties in management buyouts (MBOs), Andrew Tuch comparatively assesses US and UK laws governing such transactions. MBOs raise the quintessential type of conflicts in M\&A transactions because they involve the board or officers of the target firm acting as owners of the buyer. As the chapter illustrates, the UK's no-conflict rule is often viewed as more severe than the US fairness rule in regulating MBOs. The chapter argues, however, that the fiduciary rules in each jurisdiction operate similarly, tasking neutral or disinterested directors with policing self-dealing and facilitating commercially sensitive responses to conflicts of interest. The comparison also reveals significant divergence between the two systems - in modes of enforcement and in disclosure requirements for deal-related practices. Nevertheless, the chapter asserts that both the US and UK may not effectively prevent fiduciary misconduct early in the MBO deal process.

\section{CONCLUSION}

As the chapters in this book demonstrate, comparative corporate governance scholarship continues to flourish. The scholarly debate continues to grapple not only with the governance changes occurring in the traditionally-studied jurisdictions of the US, UK, Europe, and Japan, but over the past decade this scholarship has come to address more extensively other economically significant countries, such as Brazil, China, and India. The literature shows that, while there is much to learn from the larger theoretical models we reference above, the comparative picture remains more complex than the one painted by the original "law and finance" discussion. This is particularly true given growing concerns around the globe with issues of sustainability and corporate purpose. The continuing evolution of corporate governance debates means that for scholars, a comparative approach to corporate governance will long prove to be insightful in understanding and analyzing corporate law generally.

80 See Umakanth Varottil \& Wai Yee Wan, Comparative Takeover Regulation: The Background to Connecting Asia and the West, in Comparative TAKeover Regulation, supra note 20, at 3, 5 (2018). 